\title{
OTOMOBİL ALIMLARINDA
} KDV İNDİRIMI

\section{(TÜRKIYE VE AB UYGULAMALARI)*}

\author{
Av. Dr. Hasan ORAL**
}

ORCID ID: https://orcid.org/0000-0002-4366-4988

DOI:

Makalenin Geldiği Tarih: 30.05.2018 Kabul Tarihi: 19.06.2018

* Bu makale hakem incelemesinden geçmiştir ve TÜBİTAK-ULAKBİM Veri Tabanında indekslenmektedir.

** Ankara Barosu. 

KDVK, KDV'de indirimine bazı sınırlamalar getirmiştir. Bu sınırlandırmalardan birisi, binek otomobillere ait KDV'nin indirim konusu yapılmasına ilişkindir. Buna göre, faaliyetleri kısmen veya tamamen binek otomobillerinin kiralanması veya çeşitli şekillerde işletilmesi olanların bu amaçla kullandıkları hariç olmak üzere işletmelere ait binek otomobillerinin alış vesikalarında gösterilen $\mathrm{KDV}$, mükellefin vergiye tâbi işlemleri üzerinden hesaplanan KDV'den indirilememektedir. KDVK'da getirilen bu sınırlama, indirim mekanizması üzerine kurulu olan KDV'nin amacına aykırılık teşkil etmektedir.

Avrupa Birliği'nde ise mükelleflerin ekonomik faaliyetleri gereği satın aldıkları mal ve hizmete ait KDV'nin tamamı indirim konusu yapılabilmektedir. AB'ye göre binek otomobillere ait KDV'nin indirim konusu yapılabilmesi için mükellefin binek otomobili ekonomik faaliyetler için kullanıyor olması ve iktisabın kişisel tüketim amaçlı olarak gerçekleştirilmemiş olması yeterli görülmektedir.

Anahtar Kelimeler: Katma Değer Vergisi, Katma Değer Vergisinde İndirim, Avrupa Birliği, Binek Otomobil, Uyumlaştırma. 


\title{
VALUE-ADDED TAX DEDUCTION FOR PASSENGER CARS IN TURKEY AND THE EUROPEAN UNION'S APPROACH
}

\begin{abstract}
VAT Law has imposed certain restrictions on VAT deduction. One of such restrictions pertain to VAT deduction concerning passenger cars. As per the said restriction, VAT expressed in purchase documents of passenger cars owned by enterprises, save for passenger cars used by enterprises that fully or partially operate in renting and various other utilisation of passenger cars, cannot be deducted from VAT calculated on the taxpayer's operations subject to taxation. This restriction stipulated by the VAT Law constitutes a breach of the VAT rationale, which is indeed based on a deduction mechanism.

On the other hand, in the European Union, entire VAT amounts for goods and services purchased by taxpayers in the context of their business operations can be subject to deduction. According to the EU approach, the taxpayer's use of the passenger car in business operations and the lack of any motive for personal use in acquisition of such passenger cars are considered to be pretexts sufficient to allow VAT deduction.
\end{abstract}

Keywords: Value Added Tax, Value Added Tax Deduction, Eurpean Union, Passenger Car, Harmonisation. 


\section{ÖNSÖZ}

Katma değer vergisi (KDV), genel tüketim vergilerinin en gelişmiş şekli olup, başta Avrupa Birliği olmak üzere, dünyanın çok sayıda ülkesinde uygulanmaktadır ${ }^{[1]}$. KDV'nin diğer gider vergilerinden ayıran en önemli özelliği, kuşkusuz ki indirim mekanizmasıdır. İndirim mekanizması ile satın alınan mal ve hizmet için ödenen KDV, satış esnasında ödenecek KDV'den indirilmekte ve bu satıştan doğan değer üzerinden vergi alınmaktadır ${ }^{[2]}$. Böylece mükellef, malı alırken ödemiş olduğu katma değeri indirim konusu yaparak ikinci kez vergilendirmenin önüne geçmektedir.

Genel prensip uyarınca KDV'de indirim hakkı, malın teslimi veya hizmetin ifası ile doğmaktadır ${ }^{[3]}$ ve KDV'de indirim mekanizmasının uygulanabilmesi genel kuraldır. Ancak Katma Değer Vergisi Kanunu (KDVK), bazı mal teslimi ve hizmet ifalarına ilişkin KDV indirimini kabul etmemektedir. KDVK'nın 30. maddesinde mükellefin vergiye tabi işlemleri üzerinden hesaplanan KDV'den bazılarını indirim konusunun dışında tutmuştur ${ }^{[4]}$. İndirim konusu dışında tutulan kalemlerden birisi, faaliyetleri kısmen veya tamamen binek otomobillerinin kiralanması veya çeşitli şekillerde işletilmesi olanların bu amaçla kullandıkları hariç olmak üzere işletmelere ait binek otomobillerinin alış vesikalarında gösterilen KDV'dir.

Ülkemizde belli koşulları taşımaları halinde ancak binek otomobillere ait KDV indirim konusu yapılabilmektedir. Çalışmamızın ilk bölümünde, ülkemizde satın alınan binek otomobillere ilişkin KDV’nin hangi koşullarda indirim konusu yapılabileceği, vergi idaresinin ve Danıştayın görüşleri çerçevesinde incelenmeye çalışılacaktır. Ayrıca binek otomobillerin giderlerine ait KDV'nin durumu da bu bölümde tartışılacaktır.

Çalışmamızın ikinci bölümünde Avrupa Birliği’nin (AB), binek otomobillere ait KDV indirimi konusuna yaklaşımı ele alınacaktır. Avrupa Birliği Adalet Divanının (ABAD), genelde vergilendirmeye, özelde ise KDV'de indirim hakkına ilişkin içtihatları, AB ve Üye Ülkelerin mevzuatına önemli katkılar

[1] BİLİCİ Nurettin, “Türk Vergi Sistemi”, Savaş Yayınevi, 39. Baskı, Şubat 2017, s. 136

[2] AKMAZ Kemal, "Yargı Kararları ve Özelgeler Işığında KDV'de İndirim”, İzmir, Kasım 2013, s. 79

[3] EBRİL Liam, BODIN Jean Paul, SUMMERS Michael Keen-Victoria, “The Modern VAT", IMF, Washington, 2001, s. 4 "Başlangıçta imalat aşamasında uygulanan KDV, 1954 yılından itibaren tüketim tipi katma değer vergisine dönüştürülmüştür.”

[4] TOLU Abdullah, ŞİMŞEK Arif, “Katma Değer Vergisinde İndirim”, Yaklaşım Yayınları, Nisan 2002, s. 159 
sağlamıştır. Binek otomobillerin KDV indirimlerine ilişkin KDV Direktifi çerçevesinde verilen ABAD kararları ile AB' nin konumuza ilişkin bakışına ışık tutmaya çalışacağız. Yine bu bölümde AB'ye üye bazı ülkelerin mevzuatlarını inceleyerek, binek otomobillere ait KDV'nin indirilmesine ilişkin hükümleri çalışmamıza yansıtmaya çalışacağız.

Sonuç bölümünde ise, AB ve Ülkemizin binek otomobillere ait KDV indirimine yaklaşımlarına ilişkin genel bir değerlendirme yapılarak, AB standartlarının yakalanması için, ülkemizin gerçekleştirmesi gereken yasal düzenlemelere dair düşüncelerimiz yer alacaktır.

\section{Türkiye'de Binek Otomobillere Ait Katma Değer Vergisi İndirimi}

KDV esas itibariyle, indirim mekanizmasına dayanan bir vergileme şekli olmakla birlikte, mevzuatta belirtilen bazı durumlarda bu hak sınırlandırılmıştır. KDVK'nın 30. maddesi “İndirilemeyecek Katma Değer Vergisi” başlığıyla, indirim konusu yapılamayacak mal teslimi ve hizmet ifalarını belirlemiştir.

KDVK’nın, KDV indirimine sınırlama getirdiği konulardan birisi, binek otomobillere ait KDV'dir. KDVK'nın 30. maddesinin b bendinde, faaliyetleri kısmen veya tamamen binek otomobillerinin kiralanması veya çeşitli şekillerde işletilmesi olanların, bu amaçla kullandıkları binek otomobillerinin alış belgelerinde gösterilen KDV hariç olmak üzere, KDV mükelleflerinin binek otomobili alımında yüklendikleri KDV indiriminin mümkün bulunmadığı ifade edilmiştir. Çalışmamızın bu bölümünde KDVK 30/b maddesinin hariç tuttuğu binek otomobilere ve bu otomobillerin giderlerine ait KDV'nin indirim durumunu tartışacağız.

\section{Binek Otomobilleri Alımında Yüklenilen Katma Değer Vergisinin İndirimi}

KDVK'nın indirilemeyecek KDV'yi düzenleyen 30. maddesinin birinci fikrasının (b) bendinde, faaliyetleri kısmen veya tamamen binek otomobillerinin kiralanması veya çeşitli şekillerde işletilmesi olanların bu amaçla kullandıkları hariç olmak üzere işletmelere ait binek otomobillerinin alış vesikalarında gösterilen KDV'nin, mükellefin vergiye tâbi işlemleri üzerinden hesaplanan KDV'den indirilemeyeceği hüküm altına alınmıştır. 
KDVK'nın 30/b maddesindeki bu düzenleme ile özel otomobillerin muvazaalı olarak işletmeye sokulması suretiyle özel tüketimin teşvik edilmemesi ve vergi kaybına sebebiyet verilmemesi hedeflenmiştir ${ }^{[5]}$.

Binek araçlara ait KDV indiriminin kabulü için KDVK'daki düzenleme, binek araçların işletmeye ait olması gerektiği yönündedir. Ayrıca faaliyetleri kısmen veya tamamen otomobillerin kiralanması veya işletilmesi olan mükellefler, binek otomobil alımındaki KDV'yi indirebilecektir. KDVK'nın öngördüğü bu şartlara daha detaylı bakmakta fayda görüyoruz.

\subsection{Binek Araçların İşletmeye Dâhil Olması}

Binek araçların işletmeye dâhil olması, işletmenin aktifinde yer alması veya envanterine kayıtlı olmasını ifade etmektedir. ${ }^{[6]}$ Bu araçlar amortismana tâbi iktisadi kıymet niteliğindedir. Zira bu araçlar işletmenin aktifinde kayıtlı veya envanterine dâhil olan ve yalnızca insan taşımaya elverişli motorlu taşıtlardır. Binek otomobillerinin çeşitli şekillerde işletilmesinden kastedilen, binek otomobilinin fiilen iktisadi bir işletme oluşturmasıdır. Binek oto kiralama şirketleri (rent a car) sürücü kursları ve taksi işletmeciliği bu kapsama girmektedir.

Binek otomobilin işletmeye ait olabilmesi ve amortismana tâbi tutulabilmesi için, trafik ve diğer işlemlerin işletme adına yapması, alış faturasının da işletme adına düzenlenmesi gerekmektedir. ${ }^{[7]}$ Danıştay vermiş olduğu kararlarında, binek otomobil giderlerine ait KDV'nin indirim konusu yapılabilmesi için, binek otomobilin işletmeye ait olması gerektiğini kararlarında vurgulamıştır. ${ }^{[8]}$

\subsection{Faaliyetleri Kısmen veya Tamamen Otomobillerin Kiralanması veya İşletilmesi Olan Mükelleflerin Binek Otomobil Alımındaki Katma Değer Vergisini İndirebilecekleri}

Binek otomobillerin kiralanması veya çeşitli şekillerde işletilmesinden kastedilen husus, binek otomobilin fiilen iktisadi işletme oluşturmasıdır. Faaliyetleri kısmen veya tamamen binek otomobillerin kiralanması veya çeşitli şekillerde

[5] KDVK'nın 30. maddenin (b) bendinin gerekçesi

[6] Danıştay 9. Dairesi, 2001/851 E., 2002/526 K. ve 07.02.2002 Tarihli Kararı; "Şirket aktifinde kayıtl olan ve şirketin faaliyetlerinde kullanıldiğı kesin olan binek otomobillere ait giderler indirim konusu yapulabilecektir."

[7] KIZILOT Şükrü, "Açıklamalı ve İçtihatı Katma Değer Vergisi Kanunu ve Uygulaması", Genişletilmiş ve Gözden Geçirilmiş 6. Baskı, Ankara, Yaklaşım Yayıncılık, 2012, s. 1361

[8] Danıştay 11. Dairesi, 1995/1944 E., 1995/2648 K. ve 18.10.1995 Tarihli Kararı 
işletilmesi olan mükellefler, bu amaçla satın aldıkları binek otomobillere ait KDV'yi indirim konusu yapabileceklerdir. Bu amaçlar gözetilmeden, işletmede kullanmak üzere satın alınan binek otomobillerine ait KDV ise, KDVK'nın 30/b hükmü uyarınca indirilemeyecektir. ${ }^{[9]}$

60 Nolu KDV Sirküleri'nin konuyla ilgili açılamasında gerçek usulde vergilendirilen taksi işletmecisi, sürücü kursu ve otomobil kiralama şirketi gibi işletmelerin faaliyetleri ile ilgili satın aldıkları binek otomobilleri nedeniyle ödenen KDV'yi indirim konusu yapılabilecektir. Bu mükelleflerin binek otomobilinin alış belgesinde gösterilen KDV'yi, ait olduğu takvim yılı aşılmamak kaydıyla, ilgili belgelerin kanuni defterlere kaydedildiği vergilendirme döneminde, bu araçların fiilen faaliyette kullanılmaya başlanılıp başlanılmadığına bakılmaksızın indirilebilecektir.

Danıştay, otomobil kiralanması ya da işletilmesi işi ile uğraşsa da mükelleflerin, işletme amacı dışında iktisap ettikleri binek otomobillerinin alış vesikalarında gösterilen KDV'nin, indirim konusu yapılamayacağına hükmetmektedir. ${ }^{[10]}$

Görüleceği üzere binek otomobilin iktisadi işletmenin faaliyetlerinde kullanılmış olması, binek otomobile ait KDV'yi indirim konusu yapmaya yetmemektedir. İdare binek otomobilin kendisinin işletilmesini kıstas almaktadır. Özel sürücü kurslarında binek otomobillerin işletildiğinin tespiti, binek otomobillerin kiralanması kadar açı değildir. Zira ekspertiz hizmeti faaliyetinde kullanılması gibi sürücü kursu hizmetinde de otomobilin kullanılması hizmet maliyetinin bir parçasını ifade etmektedir. Ancak idare, özel sürücü kurslarında

[9] Danıştay 3. Dairesi, 2008/815 E., 2009/78 K. ve 22.01.2009 Tarihli Karar1; "Yasa koyucu, işletmeye ait binek otomobillerden sadece kiralanan veya işletilenler için indirim hakkı tanımıs, bu amaç dı̧̧ıda iktisap edilenler için yüklenilen katma değer vergisinin indirimini ise yasaklamıştır."

[10] Danıştay 9. Dairesi, 1995/884 E., 1996/77 K. ve 16.01.1996 Tarihli Kararında, Katma Değer Vergisi Kanunu'nun 30/b maddesinde indirim konusu yapılmamanın otomobilin özel işlerde kullanılması şartına bağlanmadığı, işletmeye ait olması ve binek otomobili olarak kullanılmasının yeterli görüldüğü, söz konusu otomobilin şirketin alacaklarının tahsilinde ve pazarlama faaliyetlerinde kullanılmasının binek otomobili olma vasfını ortadan kaldırmayacağı, bu nedenle binek otomobili olduğu konusunda ihtilaf bulunmayan otomobilin alımı sırasında ödenen katma değer vergisinin indirime tâbi tutulması nedeniyle ikmalen salınan katma değer vergisinde kanuna aykırılık bulunmadığına hükmetmiştir. Danıştay 9. Dairesi, 2005/697 E., 2006/3400 K. ve 26.09.2006 Tarihli Kararında, "Araba kiralama işi ile uğraşan şirketin, oto kiralama faaliyetinde kullanmadiğı binek otomobillerine ilişkin olarak yüklendiği KDV'yi indirim konusu yapması mümkün değildir” hükmüne varmıştır. 
kullanılmak üzere alınan binek otomobillere ait KDV'nin indirim konusu yapılmasını kabul etmektedir ${ }^{[1]]}$.

KDV Genel Uygulama Tebliğì' nin “2. İndirilemeyecek KDV” bölümünde; mükelleflerin işletme amacı dişında iktisap ettikleri binek otomobillerinin alış vesikalarında gösterilen $\mathrm{KDV}^{\prime}$ nin indirim konusu yapılamayacağı, indirim konusu yapilamayan bu verginin, Gelir ve Kurumlar Vergisi Kanunları çerçevesinde işin mahiyetine göre gider veya maliyet unsuru olarak dikkate alınabileceği belirtilmiştir.

\section{Binek Otomobillerin Giderlerine Ait Katma Değer Vergisinin İndirimi}

Binek otomobilin giderlerinden, binek otomobillere ait akaryakıt, tamir, bakım, onarım vb. giderler kastedilmektedir. Bu giderlerin KDV indirimine tabi olup olmayacağına ilişkin uygulama, Gelir Vergisi Kanunu'nun (GVK) 40/5. maddesindeki parantez içindeki hükmün, 4369 sayılı Kanun ile 01.01.1999 tarihinden itibaren geçerli olmak üzere kaldırılması ile boyut değiştirmiştir ${ }^{[12]}$. GVK'da yapılan değişikle, kiralama yoluyla edinilen veya işletmeye dahil olan ve işte kullanılan taşıtların giderlerinin indirimine ilişkin sınırlama kaldırılmış, mükellef üzerindeki vergisel yükümlülügün hafifletilerek kayıt dışılığın azaltılması ve vergi gelirinin arttırılması hedeflenmiştir.

GVK'nın 40/5. maddesindeki bu sınırlandırma esas olarak, işletmelerin esas faaliyet konularına giren işlerin yürütülmesi bakımından kullanımı zorunlu olmayan ya da işletme sahipleri ve yöneticileri, personeli tarafından makam veya servis aracı olarak kullanılan binek otomobillerin tamir, bakım, onarım, yakıt vb. giderlerine ilişkindir. Esas faaliyet konuları binek otomobillerin kiralanması olan kiralanma şirketleri, sürücü kursları, taksi işletmeciliği vb. işletmeler, GVK'nın 40/5. maddesi kapsamı dışındadır.

İşletmeye dahil olan ve kiralama yoluyla edinilen binek otomobillerin yakıt, tamir, bakım, onarım ve benzeri giderlerinin yarısını, safi kazancın tespitinde indirilecek gider olarak öngören GVK'nın 40/5. maddesinin 4008 sayılı Kanunla eklenen parantez içi hükmü, 4369 Sayılı Kanun'un 82/3. maddesiyle 01.01.1999 tarihinden itibaren yürürlükten kaldırılması ile binek otomobillerin

[11] Maliye Bakanlığı, 25835 Sayılı ve 11.06.1996 Tarihli Özelgesi

[12] GVK'nın 4369 sayılı Kanunla değişmeden önceki 40/5. maddesine göre işletmeye dahil olan veya kiralama yoluyla edinilen binek otomobillerin tamir, bakım, akaryakıt, onarım vb. giderlerinin ancak yarısı safi kazancının tespitinde indirilecek gider olarak, diğer yarısı ise kanunen kabul edilmeyen gider olarak nitelendirilmekteydi. 
giderlerine ait KDV indiriminin yarısı ile sınırlı olması durumu da ortadan kalkmış olmaktadır.

GVK'nun 40/5. maddesinde kiralama yolu ile edinilen veya işletmeye dahil olan ve işte kullanılan taşıtların giderlerinin ticari kazancın tespitinde gider olarak dikkate alınacağı, yine GVK'nun 57/5. maddesinde zirai tesisat, makine ve taşıtların çalıştırılması ve bakımı için yapılan giderler ve tamir giderlerinin zirai kazançtan düşüleceği belirtilmişti. Bu düzenlemelere ek olarak GVK’nun 68/5. maddesinde de kiralanan ve envantere dahil olan ve işte kullanılan taşıtlara ait giderlerin, serbest meslek kazancında gider olarak dikkate alınacağ belirtilmiştir ${ }^{[13]}$.

Bu kanuni düzenlemelerden de anlaşılacağı üzere işletmeye dahil olan veya işletmede kullanılmak üzere kiralanan binek otomobillerin tamir, bakım, onarım, yakıt ve benzeri giderlerine ait KDV'nin tamamı indirim konusu yapılabilecektir. Ancak mevzuatta aksine bir düzenleme olmamasına rağmen, vergi idaresince işletmenin aktifine dahil olmayan binek otomobillerin giderlerine ait KDV'nin indirim konusu yapılması kabul edilmemektedir ${ }^{[14]}$.

Danıştay da, idarenin özelgesini teyit etmektedir. Danıştay vermiş olduğu kararlarında, binek otomobile ait yakıt, tamir ve benzeri giderlerine bağlı vergi indirimini KDVK'nın 30. maddesinde göre değerlendirilmemesi gerektiği, bu giderlerin bütünüyle indirim konusu yapılabileceği belirtilmiştir ${ }^{[15]}$. Danıştay, binek otomobilin giderlerine ait KDV'nin indirim konusu yapılabilmesi için,

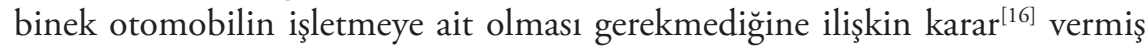
ise de, daha ileri tarihlerde, binek araçlara ait giderlerin indirim konusu yapı-

[13] Danıştay 7. Dairesi, 1987/188 E., 1988/320 K. ve 03.02.1988 Tarihli Kararı; "Şirket aktifinde kayıtlı binek otomobillerin amortisman, servis ve bakim masraflarmın gider yazılmasının yerinde olduğu, akaryakıt satıcılarının fireden dolayı uğradıkları zararı karşılamak üzere, fire payı malı alırken peşin olarak ödendiğginden ayrıca fire nedeniyle kayıtlara gider veya zarar yazılması söz konusu değildir."

[14] Maliye Bakanlığı, GİB, B.07.0.GEL.0.44/4405-1380/6984 Sayılı ve 20.02.2004 Tarihli Özelge

[15] Danıştay 7. Dairesi, 1987/1535 E., 1990/987 K. ve 13.04.1990 Tarihli Kararı;

Danıştay 9. Dairesi, 2001/851 E., 2002/526 K. ve 07.02.2002 Tarihli Karar1; "Şirket aktifinde kayıtl olan ve şirketin faaliyetlerinde kullanıldığı kesin olan binek otomobillere ait giderler indirim konusu yapulabilecektir."

[16] Danıştay 9. Dairesi, 1994/1807 E., 1994/5100 K. ve 15.12.1994 Tarihli Karar1; “... 1992 yılında anılan sözleşme gereği pazarlama satıs ve dăğtım faaliyetinde kullanılan 13 aracın toplam ... lira tutarındaki benzin, motorin, tamir ve bakım giderlerine ilişkin katma değer vergisinin; araçlar yükümlü şirketin aktifinde kayttl olmasa dahi yükümlü şirketle ilgili işlerde kullanılmış olmaları karşııında giderlerin aracın değil işletmenin giderleri olarak kabulü 
labilmesi için binek aracın işletmeye ait olması gerektiğini vurgulamıştı ${ }^{[17]}$. Yine işletmede kullanılmak üzere binek otomobillere ait giderlerin de indirim konusu yapılabileceği Danıştay kararlarında belirtilmiştir ${ }^{[18]}$.

Danıştay kararlarında, işletmede kullanılan binek otomobillerin giderlerine ait KDV'nin indirim konusu yapılabilmesi için, bu araçların işletmede kullanılması, ortakların şahsi işlerinde kullanılmaması vurgusunu yapmaktadır ${ }^{[19]}$.

Danıştayın binek otomobillere ait KDV indiriminin kabulüne ilişkin kıstas aldığı bir diğer konu da, değer artırıcı giderlerdir. Bu giderler, bir iktisadi kıymetin maliyet bedelini artıran giderlerdir ${ }^{[20]}$.

Özbalcı'ya göre değer artırıcı giderler, vergi hukuku bakımından ilk iktisap gibi değerlendirilmek durumundadır. İlk iktisapta ödenen KDV'nin indirilmesi kabul edilmeyince, binek otomobile ait ve Vergi Usul Kanununun 272. maddesinde belirtilen nitelikte bulunan değer artırıcı giderlere ait KDV'nin de indirilmesinin mümkün olmaması gerekir ${ }^{[21]}$. Nitekim Danıştay da, binek otomobillerde meydana gelen hasarların giderlerine ait KDV ile binek otomobilin çalışmasını temin etmek için yapılan bakım ve onarım giderlerine ait KDV'yi, binek otomobilin değerini artırıcı nitelik taşımaması halinde indirim konusu yapılabileceğini kabul etmiştir ${ }^{[22]}$.

\section{Avrupa Birliği’nin, Avrupa Birliği Adalet Divanının ve Bazı Üye Ülkelerin Binek Otomobillere Ait KDV İndirimine Yaklaşımı}

KDV'de indirimin $\mathrm{AB}$ mevzuatında ve yargı kararlarında en göze çarpan özelliği, bir "hak" olarak ifade edilmesidir. KDV indiriminin bir hak olduğuna

gerektiğinden ve söz konusu giderlere ilişkin katma değer vergisinin indirilmesi ticari icaplara uygun bulunduğundan mahkemece yazıl gerekçeyle tesis edilen kararda isabet görülmemiştir."

[17] Danıştay 11. Dairesi, 1998/4966 E., 1999/4971 K. ve 13.12.1999 Tarihli Kararı

[18] Danıştay Vergi Dava Daireleri Kurulu, 1997/385 E., 1998/459 K. ve 25.12.1998 Tarihli Kararı;

Danıştay 3. Dairesi, 1999/1875 E., 2000/3855 K. ve 23.11.2000 Tarihli Kararı

[19] Danıştay 9. Dairesi, 1997/4349 E., 1998/3801 K. ve 21.10. 1998 Tarihli Kararı

[20] VUK'nun 272. maddesinde, normal bakım, tamir ve temizleme giderleri dışında, gayrimenkulü genişletmek veya iktisadi kıymetini devamlı olarak artırmak maksadıyla yapılan giderlerin maliyet bedeline ekleneceği belirtilmiştir.

[21] ÖZBALCI Yılmaz, "Katma Değer Vergisi Kanunu Yorum ve Açıklamalar”, Oluş Yayıncılık A.Ş., Şubat 2012, s. 737

[22] Danıştay 11. Dairesi, 1997/2526 E., 1999/1160 K. ve 25.03.1999 Tarihli Kararı 
ilişkin vurgu, AB'nin yasal dayanağını teşkil eden direktiflerinde, ABAD kararlarında, Üye Devletlerin mevzuatlarında sıklıkla vurgulanmaktadır.

KDV indiriminin mevzuatta bir hak olduğuna ilişkin vurguya paralel olarak, AB'nin mahkemeleri olan ABAD ve Avrupa İnsan Hakları Mahkemesi ile Üye Devletlerin yargı içtihatlarında, KDV indiriminin bir hak olduğu ölçütü özellikle dikkate alınmıştır. Dolayısıyla AB'de KDV indiriminin amacını ve kapsamını belirlemeye çalıştı̆̆ımızda karşımıza çıkan en önemli unsur, KDV indiriminin mükellef lehine kullanılan bir hak olduğudur.

Binek otomobillere ait KDV'de de AB'nin yaklaşımı yine, KDV indiriminin hak olduğu ölçütü üzerinden şekillenmiştir. Bu bölümde, AB'nin binek otomobillere ait KDV indirimine yaklaşımını, Katma Değer Vergisi Direktifi (KDV Direktifi), ABAD kararları ve Üye Ülkeler perspektifinden değerlendirmeye çalışacağız.

\section{Katma Değer Vergisi Direktifi'nin Yaklaşımı}

KDV Direktifi'nin 168. maddesi, mükellef sıfatıyla hareket edilen ekonomik faaliyetleri KDV'de indirim kapsamında görmüştür ${ }^{[23]}$. Madde hükmüne göre mal ve hizmet iktisap eden kişi öncelikle, bunları ekonomik faaliyetleri için kullanıyor olmalıdır. İktisabın kişisel tüketim amaçlı olarak yapılması gibi ekonomik faaliyetler dışında, yalnızca yatırımcı sıfatıyla hareket edilen işlemler için yapılması da, KDV indirim hakkının doğmadığı halleri oluşturacaktır. Ayrıca bu ekonomik faaliyetlerin, KDV yönünden mükellef sıfatıyla hareket edilen, dolayısıyla indirim hakkını gündeme getirebilecek niteliğe sahip olması gerekir.

[23] Katma Değer Vergisi Direktifi'nin 168. Maddesi: "Mallar ve hizmetler mükellefin vergilendirilmiş işlemleri amacıyla kullanıldığı ölçüde, mükellef aşağıdaki kalemleri bu işlemleri yürüttüğü üye devlette ödemekle yükümlü olduğu katma değer vergisinden indirme hakkına sahip olacaktır:

(a) Bir diğer mükellef tarafından yürütülen veya yürütülecek mal veya hizmet temini nedeniyle o üye devlette ödeme yükümlülüğü bulunan veya ödenmiş katma değer vergisi, (b) Madde 18(a) ve 27 kapsamında mal veya hizmet iktisabı olarak kabul edilen işlemler nedeniyle ödeme yükümlülüğü bulunan katma değer vergisi,

(c) Madde 2(1)(b)(i) kapsamında Topluluk içi mal iktisabı nedeniyle ödeme yükümlülüğü bulunan katma değer vergisi,

(d) Madde 21 ve 22 kapsamında Topluluk içi mal iktisabı nedeniyle ödeme yükümlülüğü bulunan katma değer vergisi,

(e) $\mathrm{O}$ üye devlete mal ithali nedeniyle ödeme yükümlülügü bulunan veya ödenmiş katma değer vergisi." 
KDV'de indirim hakkına dayanak teşkil eden metinler, direktiflerdir. AB'ye Üye Devletler, indirim hakkına ilişkin düzenleme içeren $1 .{ }^{[24]}, 2 .{ }^{[25]}, 6$. Direktifler ${ }^{[26]}$ ve KDV Direktifi' ${ }^{[27]}$ mevzuatlarında kriter almakta ve KDV'de indirim hakkına ilişkin uygulamalarını direktif hükümlerine göre şekillendirmektedir ${ }^{[28]}$. Yine ABAD da, KDV'de indirim hakkına ilişkin kararlarında Direktif hükümlerini esas almaktadır.

KDV Direktif'inde, KDV indirimi düzenlemelerine 167 ila 171. madde kapsamında yer verilmiştir. İndirim hakkının yanı sıra iade mekanizması/hakkı da Direktif'in bu kısmında düzenlenmektedir. Temel hükümler olarak, KDV Direktifi'nin 167. maddesi indirim hakkının kaynağını, bir başka deyişle vergi indirim hakkının maliye yönünden hangi olayla doğacağını, KDV Direktifi'nin 168. maddesi indirim hakkının kapsamını, bir başka deyişle indirim hakkının hangi işlemler yönünden KDV için kullanılabileceğini belirlemektedir.

Bunlara ek olarak, KDV Direktifi' nin 169. maddesi hükmü, indirim hakkının 168. madde çerçevesindeki genel düzenleme dışında doğacağı bazı özel halleri düzenlemektedir. Bu yönden, KDV Direktifi'nin esas olarak 6. Direktif'in sistematiğini koruduğu, genel düzenlemenin (6. Direktif'te Madde 17(2)) ardından yine indirim hakkı doğuran özel hallere (6. Direktifte 17(3)) yer verdiği söylenebilir. Ancak burada temel farklılık 6. Direktif'in özel haller yönünden indirim veya iade hakkından bahsetmesine karşılık, KDV Direktifi' nin bu haller yönünden yalnızca indirim hakkının tanınması yönünde hüküm içermesidir.

KDV Direktifi'nde, KDV'nin indirim hakkının kapsamına ilişkin temel kıstas getirilmiştir. Üye Devletler mevzuatlarında bu kıstasları dikkate alarak, temin edilen mal ve hizmete ait KDV'nin indirim konusu yapılıp yapılamayacağı, indirim hakkını kullanmak isteyen kişi/tüzelkişinin bu hakka sahip olup olmadığının tespitini yapacaktır.

KDV Direktifi'nin getirmiş olduğu kıstasların ilki, mükellef sıfatıyla hareket edilen ekonomik faaliyetlerin KDV kapsamına alınmasıdır. Buradaki mükellef kavramı ile kast edilen husus, kişinin KDV mükellefi olmasıdır.

[24] 11.04.1967 Tarihli 67/227/EEC Sayılı Konsey Direktifi

[25] 11.04.1967 Tarihli 67/228/EEC Sayılı Konsey Direktifi

[26] 17.05.1977 Tarihli 77/388/EEC Sayılı Konsey Direktifi

[27] 01.01.2007 Tarihli 2006/112/EC Sayılı Konsey Direktifi

[28] BİLİCİ Nurettin, "Türkiye Avrupa Birliğgi İlişkileri, (Genel Bilgiler, İktisadi-Mali Konular, Vergilendirme)”, Seçkin Yayınları, Ankara 2007, s. 207 
Diğer kıstas ise, mükellefin vergilendirilmiş işlemlerinin niteliğidir. Mükellefin gerçekleştirmiş olduğu işlemin KDV'den istisna olması halinde, indirim hakkı doğmamaktadır.

KDV Direktifi'nin belirlemiş olduğu kıstaslar, Binek otomobillere ait KDV açısından da kuşkusuz geçerlidir. Binek otomobil satın alan kişi, KDV Direktifi'nin getirmiş olduğu kıstas gereği, mükellef sıfatıyla ve KDV mükellefiyetinin gerektirdiği iş için binek otomobili satın almış olması gerekmektedir. KDV mükellefi, söz konusu binek otomobili ekonomik faaliyetleri için kullanmalıdır. Aksi halde, binek otomobilin KDV mükellefiyeti gereği satın alınmaması ya da satın alan kişinin/şirketin KDV mükellefi olmasına rağmen binek otomobili ekonomik faaliyetinin dişında kullanması halinde KDV Direktifinin 168. maddesi, binek otomobile ait KDV'nin indirimine imkan tanımamaktadır.

KDV Direktifi'nin belirlemiş olduğu diğer bir kıstas ise, mükellefin gerçekleştirmiş olduğu işlemin KDV'den istisna tutulmasıdır. KDV Direktifi 168. maddesi içeriğinde kullanılan “vergilendirilmiş işlemler” ifadesi, KDV'de indirim hakkının kapsamının belirlenmesinde bir diğer temel kıstası gündeme getirmektedir. Bu düzenlemeye göre kişiler, mükellef sıfatıyla ekonomik faaliyetlerde bulunabilirler. Bir başka deyişle, mükelleflerin vergiye tâbi işlemleri söz konusu olacaktır. Ancak vergiye tâbi bu işlemler çeşitli nedenlerle bilfiil vergilendirilmeyebilir, istisna kapsamına alınabilirler. KDV Direktifi'nde kullanılan ifadeden yola çıkıldığında, iktisap edilen mal ve hizmetlerin ekonomik faaliyetler amacıyla kullanılmaları durumunda dahi, istisna kapsamındaki işlemler söz konusu olması halinde, mükelleflerin bunlar üzerinde KDV indirimi hakkından yararlanamayacakları sonucuna ulaşılmaktadır ${ }^{[29]}$.

KDV Direktifi'nin 2(1)(a) maddesi uyarınca, mükelleflerin Üye Devletler sınırları içinde vergilendirilebilir mal ve hizmet tedarikleri KDV kapsamına dâhil olmaktadır ve bu tedarikler vergiye tâbi işlemler olarak nitelendirilirler. Vergiye tâbi işlemlerin çoğunluğu vergilendirilir. Diğer bir bölümü ise örneğin KDV Direktifi'nin 132. maddesi hükmünce öngörülen kamu yararına faaliyetler gibi işlemler, istisna kapsamında yer alırlar. Vergiye tâbi bulunmayan, bir başka

[29] Avrupa Birliği Adalet Divanı, Uudenkaupungin Kaupunki, C-184/04 Esas, ECR I-3039 Sayılı ve 30.03.2006 Tarihli Kararı (Paragraf 24), http://curia.europa.eu/; "İktisap edilen mal ve hizmetler üzerindeki vergilerde indirim sonuç işlemler üzerindeki vergilerin tahsil edilebilir olmasıyla bağlantılıdır. Mükelleflerin mal ve hizmetleri katma değer vergisinden istisna bulunan veya katma değer vergisine tâbi bulunmayan işlemleri amaçlayarak kullanmaları halinde, bu işlemlerden kaynaklı vergi tahsil edilemeyeceği gibi, bu işlemler için iktisap edilen mal ve hizmetler üzerinde vergi indiriminden de söz edilemez. Mal ve hizmetlerin ancak vergilendirilebilen işlemler amacıyla kullanılmaları halinde bunlar üzerindeki vergi indirime tâbi olur ki, mükerrer vergilendirme önlenebilsin.” 
deyişle ne vergilendirilen, ne de vergiden istisna olan işlemler ise vergilendirilebilir olmayan işlemler olarak nitelendirilirler. KDV yönünden ifade edildiğinde ise, bu işlemler $\mathrm{KDV}$ düzenlemelerinin kapsamı dışında yer alan işlemlerdir.

Görüleceği üzere KDV Direktifi, mal ve hizmetlerin KDV'den istisna tutulmalarını, Üye Devletlerin takdirine bırakmıştır. Vergiden istisna tutulacak mal ve hizmetlerin kapsamı ise, KDV Direktif'inin 132. maddesince "kamu yararı" kıstası ile sınırlandırılmıştır. Dolayısıyla KDV Direktifi, Üye Devletlerce istisna kapsamına alınmaması halinde, mükellef sıfatıyla ve KDV mükellefiyetinin gerektirdiği iş için satın alınan binek otomobillere ilişkin KDV'nin indirim konusu yapılmasına imkan tanımaktadır.

\section{Avrupa Birliği Adalet Divanının Yaklaşımı}

KDV'de indirim hakkının kapsamına ilişkin ABAD'ın belirlemiş olduğu kıstaslar bulunmaktadır. Bu kıstaslar, her ne kadar KDV Direktifi'ndeki kıstaslardan farklılık içermese de, KDV Direktifi'nde belirtilen kıstaslara açıklık getirmekte, yorumlamakta ve ciddi katkı sağlamaktadır.

ABAD içtihatlarında, KDV Direktifi'nin içeriğine aykırı olmayan, tersine KDV Direktifi'nin belirlemiş olduğu çerçeve içerisinde kalan ve KDV indiriminin kapsamını belirleyen en önemli ölçüt, "doğrudan ve dolaysız bağlantı"nın varlığıdır. ${ }^{[30]} \mathrm{ABAD}$, bu kıstas çerçevesinde nedensellik bağını, KDV'de indirimin kabulü açısından ölçüt olarak getirmiştir.

Her bir aşamada hesaplanan KDV'den, bir önceki aşamanın vergisinin düşürülmesi olarak ifade edilen indirim hakkına ancak belirli ve sınırlı hallerde sınırlama getirilebileceği, ABAD’ın yerleşmiş içtihatlarıyla saptamıştır. ${ }^{[31]}$

[30] Avrupa Birliği Adalet Divanı Investrad BV - Hollanda Maliye Müsteşarlığı, C-435/05 Esas, 08.02.2007 Tarihli Kararı, http://curia.europa.eu/; Investrad BV - Hollanda Maliye Müsteşarlığı kararında, salt yatırım şirketi olarak faaliyet gösterirken danışmanlık hizmetleri vermeye başlayan ve bu suretle KDV mükellefi konumuna geçen şirketin, yatırım şirketi döneminde yaptığı hisse satışı üzerindeki uzlaşmazlığa ilişkin tahkim hizmetleri giderlerinin katma değer vergisi indirimi kapsamına alınması gerektiği görüşüne karşı Avrupa Birliği Adalet Divanı “... Investrad'ın bu hizmetlere ilişkin olarak masraflarının, şirketin vergiye tâbi işlemleri amacıyla ve bu işlemler gözetilerek yapılmış olduğunu varsaymak mümkün olmayacaktır. Yapılan masrafların münhasır nedeni bu türden işlemler arasında bulunamadığı için, masraflar ile ekonomik faaliyetler arasında doğrudan ve dolaysız bir bağlantı bulunmamaktadır" gerekçesiyle indirim hakkının doğmayacağına hükmetmiştir.

[31] Avrupa Birliği Adalet Divanı, BP Supergas-Yunanistan, C-62/93, ECR I-1883 Sayılı ve 06.07.1995 Tarihli Kararı; http://curia.europa.eu/

Avrupa Birliği Adalet Divanı, Gabalfrisa ve Diğerleri, C-110/98 to C-147/98, ECR I-1577 Sayılı ve 21.03.2000 Tarihli Kararı; http://curia.europa.eu/ 
AB'de ilke olarak, KDV indirimi hakkına sahip olan mükellefler, yalnızca üretim amaçlı olarak ekonomik faaliyetlerinde kullanılmak üzere mal ve hizmet iktisap edenlerdir. Buradaki en önemli amaç üretimin teşvik edilmesidir. Üretime yönelik olmayan türde, kişisel tüketime yönelik mal ve hizmet iktisap edenler indirim hakkından yararlanamamaktadır. Böylece üretim amaçlı olarak ekonomik faaliyet gösteren mükellefler, bu amaçlarla iktisap ettikleri mal ve hizmetler üzerinde tahakkuk eden KDV yönünden indirim hakkına sahip olacaklardır.

İndirim hakkının üretime yönelik olarak iktisap edilen mal ve hizmetler yönünden oluşturulmasının amacı, mükellefleri ekonomik faaliyetleri çerçevesinde gerçekleşen KDV'nin yükünden tamamen kurtarmaktır. Bu nedenle esas olan, KDV'nin tam indirim hakkının konusu haline getirilmesidir ${ }^{[32]}$.

ABAD kararlarında, mükellefin ekonomik faaliyet amaçlı iktisap edilen mal ve hizmetlere ait KDV'nin indirim hakkını kullanması, KDV Direktifi 167. maddesinde de hükmedildiği üzere, ancak vergiye tâbi işlemler için kullanıldığı kapsamla sınırlanmaktadır. ABAD’ın binek otomobillere ait KDV'nin indirimi hakkındaki temel kararı, Hansgeorg Lennartz - Finanzamt München kararıdır. ${ }^{[33]}$

Söz konusu karara göre, mali müşavir otomobil satın almış, bunu önceleri tamamen kişisel amaçlı olarak kullanmıştır. Ancak ertesi yıl otomobili daha çok iş amaçlı kullanmaya başlamış ve bu nedenle, otomobilin satın alınmasından kaynaklı olarak KDV'den indirim konusu edilmesini talep etmiştir. Vergi dairesi bu talebi otomobilin kişisel kullanım amacıyla satın alındığı, mükellefin iktisap edilen malı kendi kararıyla ekonomik faaliyetlerde kullanmaya başlamasının vergi hukuku açısından bir farklılık doğurmayacağı gerekçesiyle reddetmiştir.

Avrupa Birliği Adalet Divanı, Securenta Göttinger Immobilienanlagen und Vermögensmanagement AG v Finanzamt Göttingen, C-437/06 Sayılı ve 13.03.2008 Tarihli Kararı; http://curia.europa.eu/

Avrupa Birliği Adalet Divanı, Finanzamt Düsseldorf-Süd v SALIX GrundstücksVermietungsgesellschaft mbH \& Co. Objekt Offenbach KG. C-102/08, ECR I-0001 Sayılı ve 14.06.2009 Tarihli Kararı; http://curia.europa.eu/

Avrupa Birliği Adalet Divanı, Avrupa Komiteleri Komisyonu-İtalya, C-78/00, ECR I-8195 Sayılı ve 25.10.2001 Tarihli Kararı. http://curia.europa.eu/

[32] Avrupa Birliği Adalet Divanı D.A. Rompelman ve E.A. Rompelman-Van Deelen Hollanda Maliye Bakanlığı, 268/83 Esas, ECR 655 Sayılı ve 14.02.1985 Tarihli Kararı (Paragraf 19). http://curia.europa.eu/; “...indirim sisteminin amacının taciri, ticari faaliyetleri çerçevesine ödenebilecek veya ödenmiş $K D V$ yükünden tamamen kurtarmak olduğu sonucuna ulaşılabilir", ifadesiyle Avrupa Birliği' nde katma değer vergisi indirimi hakkının amacını açıç̧a ifade etmiştir.

[33] Avrupa Birliği Adalet Divanı, Hansgeorg Lennartz - Finanzamt München III, C-97/90 Esas Sayılı ve 11.07.1991 Tarihli Kararı. http://curia.europa.eu/ 
Ortaya çıkan uyuşmazlıkta $A B A D$, mükellefin otomobili ilk yıl münhasıran kişisel ihtiyaçlar için kullanmasının değerlendirme için yeterli olmadığını ifade etmiştir. ABAD’a göre “... vakadaki tüm haller dikkate alınarak, bu kapsamda, ilgili mallarmn nitelikleri, mallarn iktisabı ile mükellefin ekonomik faaliyetlerinde kullanılmaları arasında geçen süre gözetilerek değerlendirme yapılmalıdır." [34] Görüleceği üzere ABAD, Üye Devletin indirim konusu yapılmak istenen binek otomobilin geçmiş yıllarda mükellefin ekonomik faaliyetinde kullanılmadığ gerekçesiyle indirim hakkını kısıtlamasını hukuka aykıı bularak, binek otomobile ait KDV’nin indirim konusu edilmesi gerektiğine hükmetmiştir.

\section{Avrupa Birliği'ne Üye Bazı Devletlerin Yaklaşımı}

AB'ye Üye Devletlerin hukuki düzenlemeleri, KDV Direktifi ve $A B A D$ kararlarıla paralellik göstermektedir. KDV Direktifi'nde, KDV'nin indirim hakkının kapsamına ilişkin temel kıstas çerçevesinde Üye Devletler, mevzuatlarını şekillendirecektir. Üye Devletler, temin edilen mal ve hizmete ait KDV'nin indirim konusu yapılıp yapılamayacağının, indirim hakkını kullanmak isteyen kişi/tüzelkişinin bu hakka sahip olup olmadığının tespitini, bu temel kıstaslar çerçevesinde yapacaktır.

Çalışmamıza açıklık getirmesi açısından AB'de önemli statüye sahip gördügümüz İngiltere, Fransa ve Almanya gibi bazı ülkelerin KDV kanunlarındaki indirim hakkına ilişkin düzenlemeleri ve binek otomobillere ait KDV indirimine yaklaşımını aktarmaya çalışacağız.

\section{1. İngiltere'nin Yaklaşımı}

İngiltere Katma Değer Vergisi Kanunu'nun 102. maddesi ve devamında "Vergi İndirim Hakkı" başlığı ve "Genel İndirim Hakkı" alt başlığı ile indirim hakkının düzenlendiğini görüyoruz. İngiltere Katma Değer Vergisi Kanunu’nun 102. maddesinde, vergi mükellefi bir kişi vergiye tâbi ekonomik faaliyetleri için,

- Mükelleften alınan mallar veya hizmetlerden doğan KDV'yi,

- İthal edilen mallara ilişkin KDV’yi,

- Topluluk içi alımlara ilişkin KDV’yi,

- Otomobil Vergisi Yasası gereğince otomobile ödenen KDV'yi indirim konusu yapabilir denilmektedir.

[34] Avrupa Birliği Adalet Divanı, Hansgeorg Lennartz - Finanzamt München Kararı, (Paragraf 21) 
İngiltere Katma Değer Vergisi Kanunu'nun 102. maddesi yanında, binek otomobillere ait KDV'den indirimini düzenleyen hükmü 114. maddedir. Bu hükme göre, maksimum kalkış ağırlığı 1,550 kiloyu geçmeyen uçak ve yapıları itibariyle asıl olarak eğlence veya spor amaçlarına yönelik binek araçlar, motosikletler, karavanlar, gemilere ait KDV indirim konusu yapılmamaktadır ${ }^{[35]}$.

Ekonomik faaliyetleri nedeniyle iktisap edilen binek otomobillere ait KDV'nin indirilmesine ise İngiltere Katma Değer Vergisi Kanunu herhangi bir sınırlama getirmemiştir.

\subsection{Almanya'nın Yaklaşımı}

Almanya Katma Değer Vergisi Kanunu'nda KDV'de indirim hakkına ilişkin düzenlemeler, Kanunu’nun 15. ve 15 (a) maddelerinde yer almaktadır. Almanya Katma Değer Vergisi Kanunu’nun 15. maddesinin 1. fikrasına göre; mal teslimi ve hizmet ifası nedeniyle yüklenilen ve fatura ile belgelenen KDV, mükellef tarafindan indirim konusu yapılabilir. Ayrıca, ithal edilen mallara ve topluluk içinde iktisap edilen mallara ait KDV indirim konusu yapilabilecektir.

Görüleceği üzere Almanya Katma Değer Vergisi Kanunu da ilgili maddesinde, KDV indirimini hak kavramı üzerine kurmuştur. Kuşkusuz ki yasal düzenlemelerde "indirim hakkı" olarak tanımlanması KDV'yi tek başına bir hak statüsüne sokmaya yetmemektedir. Ayrıca getirilen kısıtlamalar da, KDV indiriminin hak niteliğine zarar verecek nitelikte olmamalıdır. Nitekim Almanya Katma Değer Vergisi Kanunu'nun 15. maddesinde mükellefin, kendi iktisadi faaliyetinde \% 10'dan az kullandığı malın iktisabı, ithalatı veya Topluluk içi iktisabı, mükellefin kendi iktisadi faaliyeti kapsamında değerlendirilemeyeceğine ilişkin hüküm, Almanya Katma Değer Vergisi Kanunu’nun indirim hakkı kavramına yaklaşımı konusunda bize önemli bir fikir vermektedir. Zira mükellefin iktisap ettiği malın \% 10'nunu kendi iktisadi faaliyetlerinde kullanıyor olması halinde bile bu mala ilişkin KDV'nin indirim konusu yapılabiliyor olması, ülkemizdeki düzenlemelerle karşılaştırıldığında Almanya’nın KDV'de indirim hakkı kavramına mükellef lehine oldukça geniş yaklaştığının önemli bir göstergesi olmaktadır.

[35] İngiltere Katma Değer Vergisi Kanununun 114. maddenin son hükmünde indirim hakkına getirilen sınırlamaya sınırlama getirilmektedir. Buna göre indirim hakkı sınırlamaları, sürüş öğretimi, ticari yolcu taşımacılığında kullanım veya kiralama veya satış amaçları için alınmış olan araçlara ve gemilere uygulanmayacaktır. Ayrıca yalnızca indirime hak tanıyan kullanım için alınmış olan binek otomobillere de, KDV'de indirim hakkı sınırlamaları uygulanmaz. 
Almanya Katma Değer Vergisi Kanunu’nun 15. maddesinin dördüncü fikrasına göre, sadece yeni taşıtların sevkiyatından, ithalatından veya Birlik için iktisabından doğan KDV, indirim kapsamındadır. İkinci el otomobillerin ithal edilmesi ile Birlik içi iktisapları, KDV indirimi kapsamı dışına çıkarılmıştır. Dolayısıyla yeni ve ikinci el taşıtların yurt içi iktisapları ve yeni otomobillerin ithalatı ve Birlik içi iktisapları nedeniyle doğan KDV indirim konusu yapilabilecektir.

\subsection{Fransa'nın Yaklaşımı}

Fransa'da KDV'de indirim hakk1, Fransa Genel Vergi Kanunu'nun 271. maddesinde düzenlenmiştir. Hükmün birinci fikrasının ilk bendine göre vergilendirilebilir işlemin fiyat unsurlarında yer alan KDV, ekonomik faaliyet neticesinde gerçekleşen KDV'den indirilebilir.

Fransa Genel Vergi Kanunu'nun 271. maddesinin birinci fikrasının ikinci bendinde ise, KDV'nin doğma anı düzenlenmiştir. Buna göre mükellefin talebi halinde KDV'den indirim hakkı doğar. İkinci bendin ikinci paragrafı ise, ilk paragrafa istisna getirmiştir. Buna göre, mükellefler, KDV'ye tâbi işlemleri sürekli yapmıyorlar ise KDV indirim hakkı sadece teslim esnasında doğar denilmektedir.

Mal ve hizmetlerin satın alınması nedeniyle yüklenilen KDV indirimi, Fransa Genel Vergi Kanunu'nun 271. maddesinin birinci fikrasının üçüncü bendine göre, indirim hakkının doğduğu ayda mükellefin hesabına geçirilebilir.

Fransa Genel Vergi Kanunu'nun 271. maddesinin ikinci fikranın birinci bendinde hangi işlemlere ait KDV'nin indirim konusu yapılabileceğini düzenlemiştir. Buna göre vergilendirilebilir mal ve hizmetlerin ekonomik faaliyetlerde kullanılması halinde mükellef, bu mal ve hizmetlere ait KDV'yi indirim hakkına sahiptir. Buna göre; mal teslimi, hizmet ifası neticesinde ödenen, Kanuna uygun olarak düzenlenen ve faturada gösterilen $\mathrm{KDV}$, ithalattan doğan $\mathrm{KDV}$, Topluluk içi satın almalardan doğan ve faturada gösterilen KDV, indirim konusu yapilabilecektir.

Fransa vergi mevzuatında, ekonomik faaliyet kapsamında iktisap edilen otomobillere ilişkin KDV'nin indirim konusu yapılabileceği düzenlenmiştir. Ancak mükellefin şahsi kullanımına tahsis ettiği binek otomobillere ilişkin, ara sıra ticari faaliyetlerinde kullanılsa bile, KDV indirim konusu yapılmasına Fransa vergi mevzuatı izin vermemektedir. Ayrıca bu otomobiller için yapılan hizmetler (taşıma, kiralama, tamir v.b.) de indirim konusu yapılamaz. Ancak Fransa Genel Vergi Kanunu'nun 273 B maddesi, binek otomobillerle ilgili sinırlamaya sınırlama getirerek, mükelleflerin, şahsi ihtiyaçları için kullandıkları kara 
taşıtlarının elektrik enerjisiyle çalışmaları halinde, normalde indirim hakkından yararlanamayan bu taşıtlar tarafından tüketilen elektrikle ilgili KDV’yi indirim konusu yapabileceklerine hükmetmiştir. Bu türden araçlar kiralandığında ve bu kiralamaya ilişkin vergi indirilebilir olmadığında da KDV indirim konusu yapilabilecektir.

\section{SONUÇ}

Mal ve hizmet alışlarındaki her aşamada, yüklenilen değerin vergisinin ödenmesi, indirim müessesesi sayesinde gerçekleşmektedir. Zira KDV, vergi indirimi müessesesi ile mükellefin mal ve hizmet alırken yüklenmiş olduğu vergiyi, satarken elde ettiği gelir için ödeyeceği vergiden indirerek, sadece elde ettiği artı değerin vergisini ödemesi amaçlanmıştır.

KDV indirimi ile çifte vergilendirmenin önüne geçilebilmekte, mükelleflerin mal ve hizmet alış verişinin otokontrolünü sağlamaktadır. Ancak KDV indirimine mevzuatımızda bazı sınırlamalar getirilmiştir. KDV İndirim kalemlerine getirilen sınırlamalardan birisi de, binek otomobillerdir.

3065 KDVK’nın 30/b maddesine göre, faaliyetleri kısmen veya tamamen binek otomobillerinin kiralanması veya çeşitli şekillerde işletilmesi olanların bu amaçla kullandıkları hariç olmak üzere işletmelere ait binek otomobillerinin alış vesikalarında gösterilen KDV, mükellefin vergiye tâbi işlemleri üzerinden hesaplanan KDV'den indirilememektedir. Binek otomobillere ait KDV indiriminin kabulü için KDVK'daki düzenleme, binek araçların işletmeye ait olması gerektiği yönündedir. Ayrıca faaliyetleri kısmen veya tamamen otomobillerin kiralanması veya işletilmesi olan mükellefler, binek otomobil alımındaki KDV'yi indirebilecektir.

Binek araçlara ait KDV indiriminin kabulü için KDVK'daki düzenleme, binek araçların işletmeye ait olması gerektiği yönündedir. Ayrıca faaliyetleri kısmen veya tamamen otomobillerin kiralanması veya işletilmesi olan mükellefler, binek otomobil alımındaki KDV'yi indirebilecektir

KDVK'nın 30/b maddesindeki bu düzenleme ile özel otomobillerin muvazaalı olarak işletmeye sokulması suretiyle özel tüketimin teşvik edilmemesi ve vergi kaybına sebebiyet verilmemesi amaç edinilmiştir. Binek otomobillerin indirim konusunda getirilen bu kısıtlayıcı düzenleme, her ne kadar vergi indiriminin kötüye kullanımını engelleme amaçlı olsa da, KDV'nin genel amacına aykırı bir durum oluşturmaktadır.

Zira binek otomobilin satın alınması esnasında; satıcı firma tarafından ilgili oranda KDV hesaplanmakta, alıcı firmadan tahsil edilmekte ve hesaplanan 
KDV olarak beyan edilmektedir. Alıcının da satın almış bulunduğu binek otomobilini ticari işinde kullanması sonucu alış sırasında ödediği KDV'yi indirim konusu yapamaması, KDV'nin indirim ilkesine uymamakta ve ticari işlemlerde haksızlığa yol açmaktadır.

Ayrıca binek otomobil işletme malvarlığına dâhil edildiğine göre, bu otomobil ileride satıldığında KDV hesaplamasına konu edilecek ve daha önce hiçbir indirim yapılmadan hesaplanan KDV'nin tamamı beyan edilip ödenecektir. Nitekim kamyon olarak tasarlandığı halde, binek araca çevrilen araçlara ait KDV indirimi, Danıştay tarafından kabul edilmemiştir. ${ }^{[36]}$ Bu durumun KDV’nin işleyişine aykırı olduğu söylenebilir.

Binek araçların alımları sırasında KDV'nin indirim konusu yapılamamasını tartışmalı kılan bir diğer konu da, işletmenin faaliyetlerinin yürütülmesinde kullanılmakta olan binek otomobilin yakıtına, tamir ve bakımına ilişkin KDV'nin indirilmesine rağmen, binek otonun alımında ödenen KDV'nin indirilememesidir. Binek aracın giderlerine ait KDV indirim konusu yapılabiliyor iken, aracın kendisine ait KDV'nin indirim konusu yapılamıyor olmasının anlaşılır bir yönü bulunmamaktadır.

AB'nin, binek otomobillere ilişkin KDV indirimine bakışı, Ülkemizin düzenlemesine göre farklılıklar içermektedir. Bu farklılıklar öncelikle KDV mükellefi kavramına yaklaşımda kendisini göstermektedir. KDV Direktifi 9 (1)de mükellef "herhangi bir ekonomik faaliyeti herhangi bir yerde, amaçlart ile sonuçlarının ne olduğuna bakılmaksızın bağımsız şekilde yürüten kişiler" ş̧eklinde tanımlanmıştır. Bu şekilde $A B$, mükellef sıfatını belirlerken, kişinin sıfat ve statüsünden çok ekonomik hayatın gerçeklerini ön plana çıkarmıştır. Böylelikle Ülkemizdeki uygulamayla karşılaştırıldığında, $A B$ 'de daha geniş mükellef kesimi, KDV indiriminden yararlanmaktadır

AB Direktiflerinde ve Üye Devlet mevzuatlarında, KDVK'nın 30. maddesinin (c) ve (d) fikralarında belirtildiği hükümler çerçevesinde, KDV indirim hakkını kısıtlayan bir düzenleme bulunmamaktadır. AB'ye göre bir mal ve hizmete ait KDV'nin indirim konusu yapılabilmesi için öncelikle, mal ve hizmet iktisap eden mükellefin, bunları ekonomik faaliyetler için kullanıyor olması ve iktisabın kişisel tüketim amaçlı olarak gerçekleştirilmemiş olması gerekmektedir. Bu nedenle $A B$, Ülkemizdeki gibi "binek araçların işletmeye dâhil olması" ve "faaliyetleri kısmen veya tamamen binek otomobillerinin kiralanması veya çeşitli şekillerde işletilmesi olanların ancak KDV indirim hakkına sahip olmaları" gibi indirim hakkının kullanmasını daraltıcı şartlar getirmemiştir. Bu nedenle KDV

[36] Danıştay 7. Dairesi, 2000/1671 E., 2001/3315 K. ve 30.10.2001 Tarihli Kararı 
indiriminden beklenen vergilendirmede otokontrolün sağlanması, mükerrer ve şelale tipi vergilendirmenin önlenmesi gibi hedeflere, Ülkemize nazaran AB'ye Üye Devletlerin daha fazla yaklaştığı söylenebilir.

Ülkemizle karşılaştırıldığında AB'nin yaklaşımı, KDV indiriminin bir hak olarak görülmesi ve KDV indirimini mükelleflerin rahatça gerçekleşmesinin sağlanması yönündedir. Ancak bu hak elbette ki sınırsız değildir. AB'de ilke olarak, KDV indirimi hakkına sahip olan mükellefler, yalnızca üretim amaçlı olarak ekonomik faaliyetlerinde kullanılmak üzere mal ve hizmet iktisap edenlerdir. Ancak bazı AB Üyesi Ülkeler, KDV Direktifi'nde çizilen sınırların da ötesine geçerek, sosyal ve çevresel nedenlerle KDV indiriminden daha da geniş kesimlerin yararlanmasına olanak sağlayabilmektedir. Nitekim Fransảda, ara sıra ticari faaliyetlerde kullanılmakla beraber, şahsi ihtiyaçlar için kullanılan elektrikle çalş̧an binek otomobillere ait KDV, indirim konusu yapılabilmektedir.

Kamu gelirinde önemli bir yeri olan KDV'nin daha verimli bir şekilde toplanması; otokontrolün sağlanması, çifte vergilendirmenin önlenmesi gibi KDV'den beklenen hedeflere ulaşılması, KDV indirim mekanizmasının sağlıklı bir şekilde işletilmesine bağlıdır. $A B$ uyum sürecinin bir parçası olan KDVK'nın kabulü önemli bir adım olmakla beraber, indirim mekanizmasının önündeki sınırlayıcı düzenlemelerin kaldırılması hem uyum sürecini hem de KDV ile amaçlanan hedeflere ulaşılmasına imkan sağlayacaktır. 


\section{KAYNAKÇA}

\section{KITTAPLAR}

Kemal AKMAZ, "Yargı Kararları ve Özelgeler Işı̆̆ında KDV'de İndirim”, İzmir, Kasım 2013

TOLU Abdullah, ŞİMŞEK Arif, "Katma Değer Vergisinde İndirim”, Yaklaşım Yayınları, Nisan 2002

Liam EBRILL-Jean Paul BODIN-Michael Keen-Victoria SUMMERS, "The Modern VAT", IMF, Washington, 2001

Nurettin BİLİCİ, "Türk Vergi Sistemi”, Savaş Yayınevi, 39. Baskı, Şubat 2017

Nurettin BİLIĊI, “Türkiye Avrupa Birliği İlişkileri, (Genel Bilgiler, İktisadiMali Konular, Vergilendirme)”, Seçkin Yayınları, Ankara 2007

Şükrü KIZILOT, "Açıklamalı ve İçtihatlı Katma Değer Vergisi Kanunu ve Uygulaması”, Genişletilmiş ve Gözden Geçirilmiş 6. Baskı, Ankara, Yaklaşım Yayınc1lik, 2012

Yılmaz ÖZBALCI, "Katma Değer Vergisi Kanunu Yorum ve Açıklamalar", Oluş Yayıncılık A.Ş., Şubat 2012

\section{ÖZELGE}

Maliye Bakanlığı, GİB, B.07.0.GEL.0.44/4405-1380/6984 Sayılıve 20.02.2004 Tarihli Özelge

\section{DANIŞTAY KARARLARI}

Danıştay 9. Dairesi, 2001/851 E., 2002/526 K. ve 07.02.2002 Tarihli Kararı

Danıştay 11. Dairesi, 1995/1944 E., 1995/2648 K. ve 18.10.1995 Tarihli Karar1

Danıştay 3. Dairesi, 2008/815 E., 2009/78 K. ve 22.01.2009 Tarihli Kararı

Danıştay 9. Dairesi, 1995/884 E., 1996/77 K. ve 16.01.1996 Tarihli Kararı

Danıştay 9. Dairesi, 2005/697 E., 2006/3400 K. ve 26.09.2006 Tarihli Kararı

Danıştay 7. Dairesi, 1987/1535 E., 1990/987 K. ve 13.04.1990 Tarihli Kararı

Danıştay 9. Dairesi, 2001/851 E., 2002/526 K. ve 07.02.2002 Tarihli Kararı 
Danıştay 9. Dairesi, 1994/1807 E., 1994/5100 K. ve 15.12.1994 Tarihli Karar1

Danıştay 11. Dairesi, 1998/4966 E., 1999/4971 K. ve 13.12.1999 Tarihli Kararı

Danıştay Vergi Dava Daireleri Kurulu, 1997/385 E., 1998/459 K. ve 25.12.1998 Tarihli Karar1;

Danıştay 3. Dairesi, 1999/1875 E., 2000/3855 K. ve 23.11.2000 Tarihli Kararı

Danıstay 9. Dairesi, 1997/4349 E., 1998/3801 K. ve 21.10. 1998 Tarihli Kararı

Danıştay 7. Dairesi, 1987/188 E., 1988/320 K. ve 03.02.1988 Tarihli Kararı

Danıştay 7. Dairesi, 1987/1535 E., 1990/987 K. ve 13.04.1990 Tarihli Kararı

Danıştay 9. Dairesi, 2001/851 E., 2002/526 K. ve 07.02.2002 Tarihli Kararı

Danıştay 9. Dairesi, 1994/1807 E., 1994/5100 K. ve 15.12.1994 Tarihli Karar1

Danıştay 11. Dairesi, 1998/4966 E., 1999/4971 K. ve 13.12.1999 Tarihli Karar1

Danıştay Vergi Dava Daireleri Kurulu, 1997/385 E., 1998/459 K. ve 25.12.1998 Tarihli Kararı

Danıştay 3. Dairesi, 1999/1875 E., 2000/3855 K. ve 23.11.2000 Tarihli Kararı

Danıştay 11. Dairesi, 1997/2526 E., 1999/1160 K. ve 25.03.1999 Tarihli Karar1

Danıştay 7. Dairesi, 2000/1671 E., 2001/3315 K. ve 30.10.2001 Tarihli Kararı

\section{AVRUPA BİRLİĞİ ADALET DIVANI KARARLARI}

Avrupa Birliği Adalet Divanı, Uudenkaupungin Kaupunki, C-184/04 Esas, ECR I-3039 Sayılı ve 30.03.2006 Tarihli Kararı http://curia.europa.eu/

Avrupa Birliği Adalet Divanı Investrad BV - Hollanda Maliye Müsteşarlı̆̆ı, C-435/05 Esas, 08.02.2007 Tarihli Kararı, http://curia.europa.eu/ 
Avrupa Birliği Adalet Divanı, BP Supergas-Yunanistan, C-62/93, ECR I-1883 Sayılı ve 06.07.1995 Tarihli Kararı; http://curia.europa.eu/

Avrupa Birliği Adalet Divanı, Gabalfrisa ve Diğerleri, C-110/98 to C-147/98, ECR I-1577 Sayılı ve 21.03.2000 Tarihli Kararı; http://curia.europa.eu/

Avrupa Birliği Adalet Divanı, Securenta Göttinger Immobilienanlagen und Vermögensmanagement AG v Finanzamt Göttingen, C-437/06 Sayılı ve 13.03.2008 Tarihli Kararı; http://curia.europa.eu/

Avrupa Birliği Adalet Divanı, Finanzamt Düsseldorf-Süd v SALIX Grundstücks-Vermietungsgesellschaft mbH \& Co. Objekt Offenbach KG. C-102/08, ECR I-0001 Sayılı ve 14.06.2009 Tarihli Kararı; http://curia.europa.eu/

Avrupa Birliği Adalet Divanı, Avrupa Komiteleri Komisyonu-İtalya, C-78/00, ECR I-8195 Sayılı ve 25.10.2001 Tarihli Kararı. http://curia.europa.eu/

Avrupa Birliği Adalet Divanı D.A. Rompelman ve E.A. Rompelman-Van Deelen - Hollanda Maliye Bakanlığı, 268/83 Esas, ECR 655 Sayılı ve 14.02.1985 Tarihli Kararı (Paragraf 19). http://curia.europa.eu/

Avrupa Birliği Adalet Divanı, Hansgeorg Lennartz - Finanzamt München III, C-97/90 Esas Sayılı ve 11.07.1991 Tarihli Kararı. http://curia.europa.eu/

Avrupa Birliği Adalet Divanı, Hansgeorg Lennartz - Finanzamt München Kararı; http://curia.europa.eu/ 
